\title{
Relative abundance of the major piercing-sucking pests and their associated natural enemies on coriander plants (Coriandrum sativum L.) in Assiut Governorate
}

\author{
(1) Salem, A.A.A.; (1) Ali, A.G. ; ${ }^{(2)}$ Samiha G. Azab; \\ ${ }^{(2)}$ Doaa S. Mohamed.; ${ }^{(1)}$ Omima S. Mahmoud \\ ${ }^{(1)}$ Plant Protection Research Institute, ARC, Giza, Egypt. \\ ${ }^{(2)}$ Zoology Department, Faculty of Science, Assiut University, Assiut, Egypt
}

\section{ABSTRACT :}

The present work was carried out at Shotb and Abnoub locations, Assuit Governorate, Upper Egypt throughout two successive coriander growing seasons, 2011/2012 and 2012/2013.The obtained results showed that coriander plants harbored 55 and 43 insect species belonging to 41,31 families and 9,9 orders in shotb and Abnoub locations, respectively. Among these species, $(29,26) ;(6,4) ;(7,4)$ and $(16,11)$ were recorded as pests, predators, parasitoids and pollinators and visitors in Shotb and Abnoub, respectively. The order Hymenoptera had the highest number of species (16, 13, species) followed by Diptera (9, 9 species) in both Shotb and Abnoub, respectively. Results also indicated that, regardless of the seasons, aphids (different species) were the most abundant piercing-sucking insect pests on coriander plants, representing $\mathbf{5 9 . 0 0}$ and $83.14 \%$, followed by T. tabaci which represented 38.12 and $15.57 \%$ of the grand total of sucking pests. The Empoascae spp. and Campylomma spp. were less abundant and represented only an average of 2.09 and $0.09 \%$ for Empoascae spp. and 1.10 and $1.19 \%$ for Capylomma spp. of the grand total of piercing-sucking pests in Shotb and Abnoub locations, respectively. Concerning the relationships between abiotic and biotic factors with the aphid populations, results also indicated that the studied variables were together responsible for $58.49 \%$ of the aphid population changes in Shotb location, while $64.57 \%$ were recorded in Abnoub location. The change of the aphid populations varied with the plant age (23.46 and $39.73 \%$ ), maximum temperature (20.34 and $12.16 \%$ ) and natural enemies (4.76 and 4.21 \%) in Shotb and Abnoub locations, respectively. Minimum temperature was found to be related with the population of aphid species only in Abnoub location (7.28 \%).

\section{INTRODUCTION}

In Egypt, Coriandrum sativum L. is an important crop that occupies a prime position in medicinal and aromatic plants. It is used in medicine as carminative and diuretic agent, as well as in the preparation of many household medicines to cure bed cold, seasonal fever, nausea and stomach disorders (Fahmy et al., 2014). It is considered as one of the most important producer countries of the medicinal and aromatic plants, because of its suitable environment. Coriander plants are subjected to be attacked by different insect species, which cause a great damage in their quality and quantity, and affecting the productivity of these plants. Piercing sucking pests are the most destructive insects on these plants 
(Butani, 1984; Ali, 1988; EL-Sayed et al., 1990; El-Sayed, 1993; EL-Kordy et. al., 1999); Afsah, 2005; and Chaudhary et.al 2009. On the other side, coriander fields may harbor beneficial insects, such as predators, parasitoids, pollinators and visitors, which play an important role in controlling the pests and subsequently improving the productivity of these plants (Rashad, 1976 and 1978; Hussein and Abd EL-Aal, 1982; AL-Qarni, 2005; Abd EL-Moniem and Abd EL-Wahab, 2006 and Abd-EL-Karim et al., 2011).

Population dynamics of destructive and beneficial species in relation to abiotic and biotic factors have been studied by (EL-Kordy et al. 1999; Abd EL-Wahab et al., 2009; Ayres and Schneider, 2009 and Khaliq et al., 2014).

The infestation of coriander plants by insect pests and associated natural enemies has received comparatively limited attention by entomologists. Thus the present work aimed to surveying of arthropod fauna in coriander fields and studying the population of the most common sucking pests and their natural enemies, as well as studying the relationship of some abiotic and biotic factors on the main pests.

\section{MATERIALS AND METHODS}

The work here was conducted in Assiut Governorate in two different locations, namely Shotb district (as clay lands, $10 \mathrm{Km}$ south-west of Assuit city) and Abnoub district (as reclaimed lands, $25 \mathrm{Km}$ north-east of Assuit city) during two coriander growing successive seasons, 2011/2012 and 2012/2013. In each location, about 0.25 feddan of coriander plants was selected yearly from field owned by local farmers, and divided into 4 equal plots .Normal agricultural practices were performed by the farmers themselves and no insecticides were applied during the study period. Sampling and entomological survey was begun by sweep-net technique when the plants started to appear above the ground. Twenty five double sweeps were taken four times from each experimental field. The collected specimens were transferred into the laboratory in plastic bags, then inspected and counted. Samples were taken weekly when the migration of insects onto the crop from overwintering sites began, and continued through the time till insect population and their natural enemies declined to lower undetectable levels.

The numbers of specimens within each inspection data were recorded. Specimens of unknown species were kept in glass vials containing $\mathbf{7 5 \%}$ ethyl alcohol for later identification. Identification was made at the Plant Protection Research Institute, Agricultural Research Center.

To study the population fluctuations of the major piercing-sucking pests, predators and parasitoids on coriander plants in both locations, the average numbers of these insects were obtained from the previously mentioned samples.

Meteorological data (temperature, relative humidity and soil temperature at 5 cm) were obtained from the Central Laboratory of Agricultural Climate for Assiut region, ARC, MOA at Giza. The relationships between abiotic (temperature, relative humidity and soil temperature at $5 \mathrm{~cm}$ ), biotic factors (plant age and natural enemies) and the population of the main piercing-sucking pests were analyzed using multiple regression analysis. 


\section{RESULTS AND DISCUSSION}

Survey of arthropod fauna associated with coriander plants:

A partial taxonomic list of pests and their natural enemies recovered by sweep-net and direct observation from coriander plants at Assiut during 2011/2012 and 2012/2013 growing seasons is presented in Table (1).

\subsection{SHOTB LOCATION:}

Data in Table (1), recorded 56 insect species belonging to 41 families pertaining to 10 orders on coriander plants in this location. Of these, 28 species were pests, 7 species were predators, 6 species were parasitoids and 15 species were pollinators and visitors. Some unidentified species of true spiders were also collected. The order Hymenoptera recorded the highest, numbers of species (16 species), followed by Diptera (9 species), Coleoptera and Homoptera (7 species for each), Hemiptera, Lepidoptera and Orthoptera (4 species for each), Neuroptera (2 species), Odonata (2 species) and Thysanoptera (single species).

\subsection{ABNOUB LOCATION:}

In this location, 43 insect species belonging to 32 families and 9 orders were found on coriander plants (Table 1). Among these species, 23 species were recorded as pests, 5 species were predators, 4 species were parasitoid and 11 species were pollinators and visitors. Unidentified species of true spiders (order, Araneida) were also counted. The Hymenopterous insects were the dominant component (13 species) followed by Diptera ( 7 species), Hemiptera and Homoptera (6 species for both), Coleoptera ( 5 species), Orthoptera ( 3 species) and orders Lepidoptera,
Neroptera, and Thysanoptera (a single species for each). The present results are in accordance with those obtained by ALQarni (2005) who recorded 63 species belonging to 9 families, 71 genera and 10 orders on coriander plants in Saudi Arabia. Abdel-Moniem and Abdel-Wahab (2006) found fourteen phytophagous insect species and six insect predators on roselle plants. Also, Ismail et al. (2010) recorded 10 insect species belonging to 8 families and 5 orders as insect pests and 8 species of predaceous insects belonging to 6 families and 4 orders on marjoram plants. It could be generally observed that, the order Hymenoptera recorded high number of species followed by Diptera. These findings are in harmony with those obtained by (Rashad, 1976 and 1978; EL-Hefny et al.1979, Yousif-Khalil et al., 1989 and Darwish et al., 1991). In addition, AL-Gamidi (2005) recorded 23, 20 and 16 hymenopterous and 10, 6 and 7 dipterious species on coriander plants in three different locations in Saudi Arabia. The author also found that, the most important genera of the hymenopterous pollinators were Andrena, Apis, Holicutus, Diles and Polistes. Mohamed and Whitney (1999) observed that $C$. sativum received high visitation by beneficial natural enemies. Chaudhary et al. (2009) indicated that coriander plants are attacked by $A$. gossypii, A. spiraecola, H. coriandri and $M$. persicae. In general, the results also indicated that there were 5 genera (Taylorilygus, Spilostethus, Galeatus, Baryscapus and Heoleracris) noticed only in Abnoub location, while 18 genera were recorded in Shotb location only 
(Anthrenus, Scymnus, Drosophila, Anopheles, Oxycarenus, Psylla, Vespa, Chrysis, Microptitis, Ephedrus, Vanessa, Cosmolyce, Agrotis, Cueta, Hemianax, Ischnura, Gryllus and Truxalis). The numbers of insect species were high in Shotb as compared with Abnoub location. This variation in the insect species on the same plant species in two different locations may be due to the mainly difference in the nature of soil in the both locations and/ or, the low establishment of arthropod fauna in Abnoub, as compared to Shotb location as a result of long periods of cultivation of the land in the latter area.

2- SEASONAL ABUNDANCE OF PIERCING-SUCKING PESTS AND THEIR NATURAL ENEMIES:

The common sucking pests in the above mentioned locations were identified as aphids (Aphis craccivora Koch, A. gossypii Glov., Myzus persicae Sulz. and Rhopalosiphum maidis Fitch), onion thrips (Thrips tabaci Lind.), leaf hoppers (Empoascae spp.) and leaf bugs (Campylomma spp.). On the other side, Coccinella undecimpunctata L., Chrysoperla carnea Steph., Syrphus corolla Fab. and Scymnus spp., were the most common predatory species, while, Diaeretiella rapae (M'Intosh), Aphidius colemani Viereck, Praon necans Mackauer, Ephedrus plagiator (Nees)) were the most common primary parasitoid species.It is noteworthy that the other pests and natural enemies were observed in very low numbers, therefore, they are not included in the present interpretation. Data of population densities expressed in terms of weekly mean numbers $/ 25$ double sweeps are summarized in Tables (2 and 3).

\subsection{SHOTB LOCATION:}

The population fluctuation of the major sap-sucking insect pests and their associated natural enemies (predator and parasitoids) were determined during 2011/12 and 2012/13 seasons on coriander plantations (Table 2).

\subsubsection{1/2012 SEASON}

Data in Table (2) indicated that the mean numbers of aphids (total aphid species) increased gradually from the 4th wk. of January with peak on March, 4 and an average of 520.00 aphids $/ 25$ net strokes. It showed gradual decrease in numbers from March, 15 till the end of the season. Onion thrips ranked the second with similar behavior of that showed by aphids. Data showed 4 peaks for their on coriander plants on February, 2 and 23, and March, 8 and 29 with an average of $175.25,310.00,84.25$ and 139.25 individuals/25 net strokes. Leaf hoppers and plant bugs ranked as the third and fourth sapsucking pests. These species showed a single peak on January, 26 and February, 23 with an average of 3.00 and 6.25 individuals/25 net strokes for leaf hoppers and leaf bugs, respectively. In this season, about 4386.50 average number of individuals collected during the whole coriander growing season, there were 3134.25 individuals of aphids represented $71.45 \%, 1228.00$ individuals of onion thrips represented $28.00 \%, 9.75$ individuals of leaf hoppers represented $0.22 \%$ and 14.50 individuals of leaf bugs represented $0.33 \%$ of the grand total of sucking pest species. Table (2) also indicated that, the predator and parasitoid species were observed in few numbers throughout the whole growing season. The maximum numbers $(2.00$ and 42.00 individuals/25 net strokes were recorded 
during the 1st wk of April for predator and parasitoids, respectively.

\subsubsection{2/2013 SEASON:}

Seasonal abundance of the main sucking pests and the associated predators and parasitoids are summarized in Table (2). The aphid species began to appear on coriander plants in extremely low numbers (8.00 aphids/25 net strokes) during the 2nd wk of January. Three peeks were recorded to this pest on January, 17, February, 7 and March, 3 with an average of $40.75,114.25$ and 95.00 aphids/25 net strokes. Numbers of aphids showed a sharp decrease and approximately vanished from the field during the beginning of April. The population of $T$. tabaci in this season occurred throughout the period extended from the 2nd wk. of January until the 1st wk. of April. It started with low numbers of 2.25 individuals/25 net strokes, and the numbers fluctuated to give four peaks, $39.75,269.75,237.50$ and 71.75 individuals/25 net strokes on the 4th, 2nd, 1st, and 4th wk. of January, February and March, respectively. The infestation of coriander plants with Empoasca spp. and Campylomma spp. began to appear during the 2nd and 3rd wk. of January, respectively. Then the population established on the plants and developed slowly to reach the highest density of $\mathbf{2 4 . 0 0}$ and 23.25 individuals/25 net strokes during 4th and 2nd wk of January and February for Empoasca spp, respectively. Meanwhile, the highest density of Campylomma spp. (10.00 individuals/25 net strokes) was recorded on the 2nd and 4th wk February and March, respectively. The present results in Table (2) also indicated that aphids, onion thrips, leaf hoppers and leaf bugs represented 23.82,
65.98, 7.07 and $3.13 \%$ of the total sap-sucking pest species recovered from coriander plants during this season. As shown in Table (2) the predator and parasitoid species were observed in association with the first detection of pests on the plants. Number of the predator and parasitoid species were fluctuated throughout the whole growing season to give two main peaks for each (23.50 and 56.50) and (11.50 and 8.50) individuals/25 net strokes during the 1st wk and 4th wk of March and the 2nd and 1st wk of February and April for the predators and the parasitoids, respectively.

\subsection{ABNOUB LOCATION:}

The change in the population densities of sucking pests and the associated predator and parasitoid species on coriander plants during 2011/2012 and 2012/2013 seasons are presented in Table (3).

\subsubsection{1/2012 SEASON:}

Table (3) showed that the individuals of aphids began to appear in the field in a relatively low level $(0.75$ aphid/25 net strokes) during the 1st wk. of February. Thereafter, the population tended to fluctuate and increase gradually through February and the beginning of March. The maximum level $\mathbf{( 3 1 9 . 5 0}$ aphids/25 net strokes) was attained during the 3rd wk. of March. The number of aphids showed a sharp decrease and approximately vanished from the field during the end of season. Onion thrips showed approximately the same trend of aphids. The population of this species reached its maximum level $\mathbf{( 2 5 . 0 0}$ individuals/25 net strokes) during the 2nd wk. of March. Leaf hoppers and leaf bugs were observed in scarce numbers throughout the whole coriander growing season. The numbers of Empoasca spp. were observed only in the 
4th and the 2nd wk. of January and March, respectively by 0.25 individuals/25 net strokes, whereas the highest level of Campylomma spp. (16.00 individuals/25 net strokes) was recorded during the 2nd wk. of March. During 2011/2012 season, about 827.25 individuals (total sucking pests) were collected from coriander fields. There were $730.75,68.75$, 0.50, 27.25 individuals represented $88.33,8.31$, 0.06 and $3.29 \%$ of aphids, T. tabaci, Empoasca spp. and Campylomma spp, respectively.

On the other side, the insect predators were detected in the field during the 4th wk. of January in few numbers (0.25 individual/25 net strokes), then declined from the field during February until the 2nd wk. of March. The maximum level (21.25 individuals/25 net strokes) was recorded during the 4th wk. of March. Concerning the aphid parasitoids, it's clear that the individuals were appeared two weeks after aphids were first observed in the field with low level (0.25 parasitoid/25 net strokes). The maximum level $(8.00$ parasitoids/25 net strokes) was recorded during the 2nd wk. of March before the maximum level of aphids by one weak.

\subsubsection{2/2013 SEASON:}

Data in Table (3) show that, aphid species were first appeared in coriander fields during the 2nd wk. of December. Its numbers increased and fluctuated to attain a peak of 305.75 aphids/25 net strokes during the 2nd wk. of February. Concerning to the population of $T$. tabaci, it is clear that, its population followed nearly the same trend as aphid populations. The pest appeared in the field from the 2nd wk. of December up to the end of the season with a peak of abundance (28.25 individuals/25 net strokes) during the 2 nd wk. of January. The Empoasca spp. and Campylomma spp. were appeared in coriander field in extremely scarce numbers during the whole growing season with a peak of 0.50 and 0.75 individuals/25 net strokes during the 4th and the 2nd wk. of February and March for Empoasca spp. and Campylomma spp., respectively. The present results also indicated that, the numbers of aphids, T. tabaci, Empoasca spp. and Campylomma spp. species represented 88.44, 11.28, 0.12 and $0.16 \%$ of the grand total of sucking pests recovered from coriander plants during 2012/2013 season.

It could be generally concluded that aphids were the most abundant sucking pests in coriander fields over two seasons and two localities represented 59.00 and $83.14 \%$ of the grand total of sucking insects in Shotb and Abnoub Locations, respectively, followed by T. tabaci which represented 38.12 and 15.57 \%. Empoasca spp. and Campylomma spp. were less abundant and represented only an average of 2.09 and $0.09 \%$ for Empoasca spp. and 1.10 and $1.19 \%$ for Campylomma spp.

Previous studies (Dawood, 1971; Hussien, 1982; EL-Gendi, 1988; Abou-Elhagag and Abdel-Hafez, 1999; and El-kordy et al., 1999 and Ismail, 2001; Pons and Lumbierres, 2004) summarized that aphids are considered to be the most serious pests and caused serious reduction in the annual yield of ornamental and aromatic plants. In addition, Ismail et al. (2010) reported that the major insect pests in marjoram field were A. gossypii, E. decipiens and Campylomma impecta. From the above mentioned results, aphids are considered the major insect pests on coriander plants during 
the period of study. Thus this investigation focuses mainly on the seasonal abundance of the aphids in relation to some abiotic and biotic factors (Tables 4, 5, 6 and 7).

\subsection{RELATIONSHIP BETWEEN SOME}

\section{ABIOTIC AND BIOTIC FACTORS WITH THE POPULATION ABUNDANCE OF APHIDS:}

Multiple regression analysis was used in order to declare the relationship between some abiotic factors (temperature, relative humidity and soil temperature at $5 \mathrm{~cm}$ ) and biotic factors (plant age and natural enemies) and the population density of aphids on coriander plants in two different studied locations (Table 8).

\subsubsection{SHOTB LOCATION:}

As shown in Table (8), simple correlation analysis revealed that plant age (x1) had significant positive relationship with the population of aphids $(r=0.52)$. Maximum temp. (x2), min. temp. (x3), min. soil temp. at 5 cm (x7) and natural enemies (x8) had negatively insignificant relation $(r=-0.37$, $0.35,-0.02$ and $\mathbf{- 0 . 0 7}$, respectively). Maximum R.H. ( $x 4)$ had significant negative relation $(r=$ $-0.45)$.

On the contrary, min. R.H. (x5) and max. soil temp. at $5 \mathrm{~cm}$ (x6) had positively insignificant relation $(r=0.13$ and 0.03 , respectively).

The coefficient of determination ( $R 2 \times$ 100) showed that the eight tested variables related to changes on aphid populations by $58.49 \%$.

The most relative factors were plant age, maximum temperature and natural enemies, since their relationship were, 23.46, 20.34 and $4.76 \%$, respectively.

\subsubsection{ABNOUB LOCATION:}

Table (8) also shows that simple correlation coefficient of the plant age (x1), max. temp. (x2) and min. temp. (x3) were highly positive significant $(r=0.63,0.65$ and 0.49, respectively). Maximum R.H. (x4), min. R.H. (x5), min. soil temp. at $5 \mathrm{~cm}(\times 7)$ and natural enemies (x8) had positively insignificant correlation $(r=0.35,0.07,0.37$ and 0.18 , respectively) but the max. soil temp. at $5 \mathrm{~cm}$ (x6) had insignificant negative correlation $(r=\mathbf{- 0 . 2 1})$. The multiple regression analysis revealed that the eight studied variables were correlated with $64.57 \%$ of the changes in the aphid populations. Most the changes in aphid populations however were correlated to plant age $(39.73 \%)$, maximum temperature $(12.16 \%)$, minimum temperature $(7.28 \%)$ and natural enemies $(4.21 \%)$.

In general, the obtained results in Shotb location revealed that the eight mentioned variables were together correlated with $58.49 \%$ of the changes of the population density of aphids.

On the other side, in Abnoub location, the eight variable were correlated together with $64.57 \%$ of changes of the aphid populations. Nearly similar results were obtained by (Sengonca and klingauf, 1973; Prasad et al., 1984; Mohamed,1986; Sharma and Yadva, 1994; Hassanein et al., 1995; EL-Kordy et al., 1999 and Abdel-Wahab et al., 2009). Regardless of location the changes of the population dynamic of aphids attributed to mainly plant age, maximum temperature and natural enemies. Khaliq et al. (2014) mentioned that, generally, both abiotic (temperature, humidity and light) and biotic factors (host, vegetative, biodiversity, 
crowding and diets) stresses significantly influence the insects and their population dynamics. In summary, the changes of the population dynamics of the aphids depends on the combination effects of plant age, weather factors (mainly maximum temperature) and natural enemies.

\section{REFERENCES}

Abd EL-Kareim, A.I.; EL-Negar, M.E. and Marouf, A.E. (2011). Survey of predaceous insects associated with four medicinal plants. J. Plant Prot. and Pathology, Mansoura University, 2 (6): 623-636.

Abd EL-Moniem, A.S.H. and Abd EL-Wahab, T.E. (2006). Insect pests and predators inhabiting roselle plants, Hibiscus sabdariffa L., a medicinal plant in Egypt. Archives of Phytopathology and plant Protec., 39(1): 25-32.

Abd EL-Wahab, H.A.; Ebrahim, S.A. and Shaalan, H.S. (2009). Evaluation of Coccinella undecimpunctata L. against Brevicoryne brassicae (Linnaeus) on dill plants. J. Agric. Sci., Mansoura University, 34(5): 5281-5288.

Abou EL-Hagag, G.H. and Abd EL-Hafez, N.A. (1999). Seasonal occurrence and relative abundance of main pests infesting caraway and cumin plants in Upper Egypt. Assiut J. Agric. Sci., 30 (4): 149-166.

Afsha, A.F.E. (2005). Studies on some pests attacking medicinal and aromatic plants. Ph.D. Thesis, Fac. Agric., Zagazig Univ.

Al-Doghairri,M.A.; and Cranshaw, W.S. (1999). Surveys on visitation of flowering landscape plants by common biological control agents in Colorado. $\mathbf{J}$. Kansas Entomological Society,72(2): 190-196.

Al-Ghamdi, A.A. (2005). Hymenopterous and Dipterous pollinators diversity on various flowering plants in Riyadh, Saudi Arabia. Assiut J. Agric. Sci., 36 (1): 69-83.

Al-Qarni, A.S. (2005).Destructive and beneficial insects associated with two medicinal plants (Coriandrum sativum and Brossica nigra) in Centeral Saudi Arabia. Minia J. Agric. Res. \& Dev., 25 (2): 329-344.

Ali, A.G. (1988). Ecological and control studies on certain pests infesting medicinal and aromatic plants. Ph.D. Thesis, Fac. Agric., Assiut Univ., 297 pp.

Ayres, J.s. and Schneider, D.S. (2009). The role of anorexia in resistance and tolerance to infections in Drosophila. Plos Biol, 7: 1000-1005.

Butani, D.K. (1984). Species and pest problems: 3-Coriander, pesticides, 18:15-17.

Chaudhary, H.C.; Singh, D.; and Singh, R. (2009). Diversity of aphids (Homoptera: Aphididae) on the field crops in Terai of Eastern Uttar Pradesh. J. Aphidology, 23(1\&2): 69-76.

Darwish, Y.A.; Hussein, M.O. and Abd-Allah, M.A. (1991). Survey of hymenopterous and dipterous pollinators on flowering cumin, caraway and anise plants in Assiut and Sohag regions. Assiut J. Agric. Sci., 22 (4): 59-68.

Dawood, M.Z. (1971). Survey of aphids and mealy-bugs infesting ornamental plants. 
M.Sc. Thesis. Fac.Agric., Cairo Univ., Egypt, 114 pp.

EL-Gendi, S.S.M.M. (1988). Ecological and biological studies on some insect pests of ornamental and medicinal plants. Ph.D. Thesis, Fac. Agric., EL-Fayoum, Cairo Univ., 170 pp.

EL-Hefny, A.M.; Abd EL-Salam, A.L.; Moustafa, A.A. and Salem, M.M. (1979). Seasonal abundance and daily activity of some an andrenid bees pollinating three different plants at Giza Governorate. Symposium Affiliated to 3rd Arab pesticide Conf., Tanta Univ., 46-53.

EL-Kordy, M.W.; Mohamed, A.A; Marzouk, I.A. and Mohamed, H.A. (1999). The changes in population density of aphids attacking some medicinal and aromatic plants in Egypt. Egypt J. Agric. Res., 77 (1): $195-204$.

EL-Sayed, A.M.; Abd EL-Galil, F.A.;Darwish, Y.A. and Abou Elhagag, G.H. (1990). Incidence and dominance of arthropods associated with roselle, caraway and coriander plants in Upper Egypt. Assuit J. Agric. Sci., 21(3): 153-165.

EL-Sayed, H.A.M. (1993). Studies on aphid fauna infesting medicinal and aromatic plants in Egypt. M.Sc. Thesis, Fac. of Agric., AL-Azhar Univ., 73 pp.

Fahmy, H. A., Shreif, N. H. and Gharib, O. A. (2014). The protective effect of Coriandium sativum extract on hepatorenal toxicity induced in irradiated rats. European J. Med. Plants, 4(3): 196-205. Hassanein, S.S.M.; Metwally, E.M.; Helaly, M.M; Desuky, W.M.H. and Al-Shannaf, H.M.H. (1995). Relative abundance of some cotton pests and the simultaneous effect of certain weather factors on their activity in Zagazig region, Egypt. Zagazig J. Agric. Res., 22 (1): 159-174.

Hussein, M.H. (1982). Population density of destructive and beneficial insects on some medicinal and aromatic plants. Assuit J. Agric. Sci., 13: 165-172.

Hussein, M.H. and Abd EL-Aal, S.A. (1982). Wild and honey bee as pollinators of 10 plant species in Assiut area. Egypt. Z. ang. Ent., 93, 342-346.

Ismail, H.A.; Kelany, I.M.; Abd EL-Megid, J.E. and Ibraheem, M.M.A. (2010). Survey and relative densities of insect pests and their predators associated with mint, roselle and marjoram at Abo-Kabir district Sharkia Governorate. Zagazig J. Agric. Res., 37 (5): 1193- 1210.

Ismail, O.M.N. (2001). Studies on some insects attacking aromatic and medicinal plants. M.Sc. Thesis, Fac. Agric., Cairo Univ., 152 pp.

Khaliq, S.; Javed, M.; Sohail, M. and Sagheer, M. (2014). Enviromental effects on insects and their population dynamics. J. of Entomol.\& Zool. Studies, 2(2): 1-7. Mohamed, M. A. (1986). Ecological studies on some sucking insects infesting cotton in Middle Egypt. Ph. D. Thesis, Fac. Agric., Minia Univ., 115 p.

Pons, X. and Lumbierres ,B (2004). Aphids on ornamental shrubs and trees in an urban area of the Catalan coast: bases foe an IPM program. Aphids in a new millennium proceedings of the six International symposium on Aphids 2001, (359-364). 
Prasad, D.; Singh, K.M.;Katiyar, R.N. and Singh, R.N. (1984). Incidence of insect pests in early maturing high yielding variety of pea, Pisum sativum Linn. Indian J. Entoml., 46 (3): 352-362.

Rashad, S.E. (1976). Experience with pollination of tropical crops. Apiculture in tropical climate, London, 109-112.

Rashad, S.E. (1978). Utilization of non Apis bees as crop pollinators. EG. ARS., 66:48 pp.

Sengonca, C. and Klingauf, F. (1973). Behaviour of an parasite and its hosts in relation to ecological factors. Verhalten eines Blattlaus Zoologische
Jahrbuscher, Systemitik, Okologie and geographic de Tiere, 100: 81-106.

Sharma, R.P. and Yadav, R.P. (1994). Population dynamics of bean aphid Aphis craccivora Koch. and its predatory coccinellid complex in relation to crop type (lentil, lathyrus and faba bean) and weather conditions. J. Ent. Res., 18 (1): 25-36.

Yousif-Khalil, S.I.; Helaly, M.N. and ELDeen,M.A. (1989). Insect population of coriander, Coriandrum sativum L. and their effect on its yield. 3rd Nat. Conf. pests \& Dis. veg. \& Fruits in Egypt: 348-363. 
Table (1): Partial taxonomic list of arthropods fauna recorded associated with coriander plants in Assiut Governorate during two successive seasons (2011/2012 and 2012/2013).

\begin{tabular}{|c|c|c|c|}
\hline Order & Family & Scientific name & Note (1) \\
\hline \multirow{7}{*}{ Coleoptera } & \multirow{2}{*}{ Dermestidae } & Trogoderma sp. & AXSE \\
\hline & & Anthrenus sp & AXS \\
\hline & \multirow{3}{*}{ Coccinellidae } & Coccinella undecimpunctata $L$. & BXSE \\
\hline & & Hippodamia convergens Guérin-Méneville & BXSE \\
\hline & & \begin{tabular}{|l} 
Scymnus spp. \\
\end{tabular} & BXS \\
\hline & Chrysomelidae & Bruchus rufimanus Boh. & AXSE \\
\hline & Scarabaeidae & Tropinota squalid Scop. & AZSE \\
\hline \multirow{9}{*}{ Diptera } & Calliphoridae & Lucilia caesar $\mathrm{L}$. & DXZSE \\
\hline & Muscidae & Musca domestica $\mathrm{L}$. & DXSE \\
\hline & Sarcophagidae & Sarcophaga carnaria $\mathbf{L}$. & DXZSE \\
\hline & Syrphidae & Syrphus corolla Fabr. & BXSE \\
\hline & Agromyziodae & Liriomyza congesta (Beck.) & AXSE \\
\hline & Ulidiidae & Physiphora alceae Preyssler & DXSE \\
\hline & Drosophilidae & Drosophila sp. & AXS \\
\hline & Culicidae & Anopheles sp. & DXS \\
\hline & Tabanidae & Tabanus eggeri Schiner & DXZSE \\
\hline \multirow{7}{*}{ Hemiptera } & \multirow{2}{*}{ Miridae } & Campylomma spp. & AXSE \\
\hline & & Taylorilygus pallidulus Blanchard & AXE \\
\hline & \multirow{3}{*}{ Lygaeidae } & Nysius graminicola Kolnati & AXSE \\
\hline & & Oxycarenus hyalinipennis Costa & AXS \\
\hline & & Spilostethus pandurus (Scopoli) & AXE \\
\hline & Anthocoridae & Orius sp. & BXSE \\
\hline & Tingidae & Galeatus scrophicus Saunders & AXE \\
\hline \multirow{7}{*}{ Homoptera } & \multirow{2}{*}{ Cicadellidae } & Empoasca decipiens Paoli & AXSE \\
\hline & & Empoasca lypica Deber. & AXS \\
\hline & Psyllidae & $\begin{array}{l}\text { Psylla sp. } \\
\end{array}$ & AXSE \\
\hline & \multirow{4}{*}{ Aphididae } & Aphis craccivora Koch & AXSE \\
\hline & & Aphis gossypii Clover & AXSE \\
\hline & & Myzus persicae Sulzer & AXSE \\
\hline & & Rhopalosiphum maidis Fitch & AXSE \\
\hline \multirow{17}{*}{ Hymenoptera } & Xylocopidae & Xylocopa aestuans L. & DZSE \\
\hline & Eumenidae & Eumenes maxillosus F. & DXZSE \\
\hline & Sphecidae & Philanthus Abd el Kader S. et F. & DXZSE \\
\hline & \multirow{2}{*}{ Vespidae } & Polistes gallica $\mathbf{L}$. & DXZSE \\
\hline & & Vespa orientalis L. & DXZS \\
\hline & Chrysididae & Chrysis nitidula F. & CXZS \\
\hline & Andrenidae & Andrena spp. & DXZSE \\
\hline & Apididae & Apis mellifera $\mathbf{L}$. & DXSE \\
\hline & \multirow{5}{*}{ Braconidae } & Microplitis sp. & CXZS \\
\hline & & Diaeretiella rapae (M'Intosh) & CXSE \\
\hline & & Aphidius colemani Viereck & CXSE \\
\hline & & Praon necans Mackauer & CXSE \\
\hline & & Ephedrus plagiator (Nees) & CXS \\
\hline & Cynipoidea & $\begin{array}{l}\text { Alloxysta sp. } \\
\end{array}$ & AXSE \\
\hline & Ceraphronoidea & Dendrocerus sp. & AXSE \\
\hline & & Chalcidus sp. & AXSE \\
\hline & Chalcididae & Baryscapus szoecsi Erdös & CXE \\
\hline \multirow{4}{*}{ Lepidoptera } & Nymphalidae & Vanessa cardui L. & AZS \\
\hline & Pieridae & Pieris rapae $L$. & AZSE \\
\hline & Lycaenidae & Cosmolyce baeticus L. & AZS \\
\hline & Noctuidae & Agrotis ipsilon Hufn. & AZS \\
\hline \multirow[t]{2}{*}{ Neuroptera } & Chrysopidae & $\begin{array}{c}\text { Chrysoperla carnea } \\
\text { Steph. }\end{array}$ & BXSE \\
\hline & Myrmeleontidae & Cueta variegate Klug. & BXS \\
\hline \multirow{2}{*}{ Odonata } & Aeshnidae & Hemianax ephippiger Selys & DZS \\
\hline & Agrionidae & Ischnura senegalensis Rambur & DZS \\
\hline & Gryllidae & Gryllus domesticus $\quad$ L. & AXZS \\
\hline & & Acrotylus insubricus Scop. & AXZSE \\
\hline Orthoptera & Acrididae & Truxalis longicornis Krauss & AXZS \\
\hline & Acrididae & Ochrilidia gracilis Krauss & AXZSE \\
\hline & & Heteracris littoralis (Rambur) & AXZE \\
\hline Thysanoptera & Thripidae & Thrips tabaci Lind. & AXSE \\
\hline Araneida & Various familes & Unidentified species & BXSE \\
\hline
\end{tabular}

These results based on weekly samples in two locations.
A -Pest
B - Predator
C- Parasitoid
D- Pollinator or\& visitor
S- Shotb
E- Abnoub
$\mathrm{X}$ - sweep net method
Z - Direct method 
Table (2): Mean numbers of piercing-sucking pests infesting coriander plants and their natural enemies, Shotb district, 2011/2012 and 2012/2013 seasons.

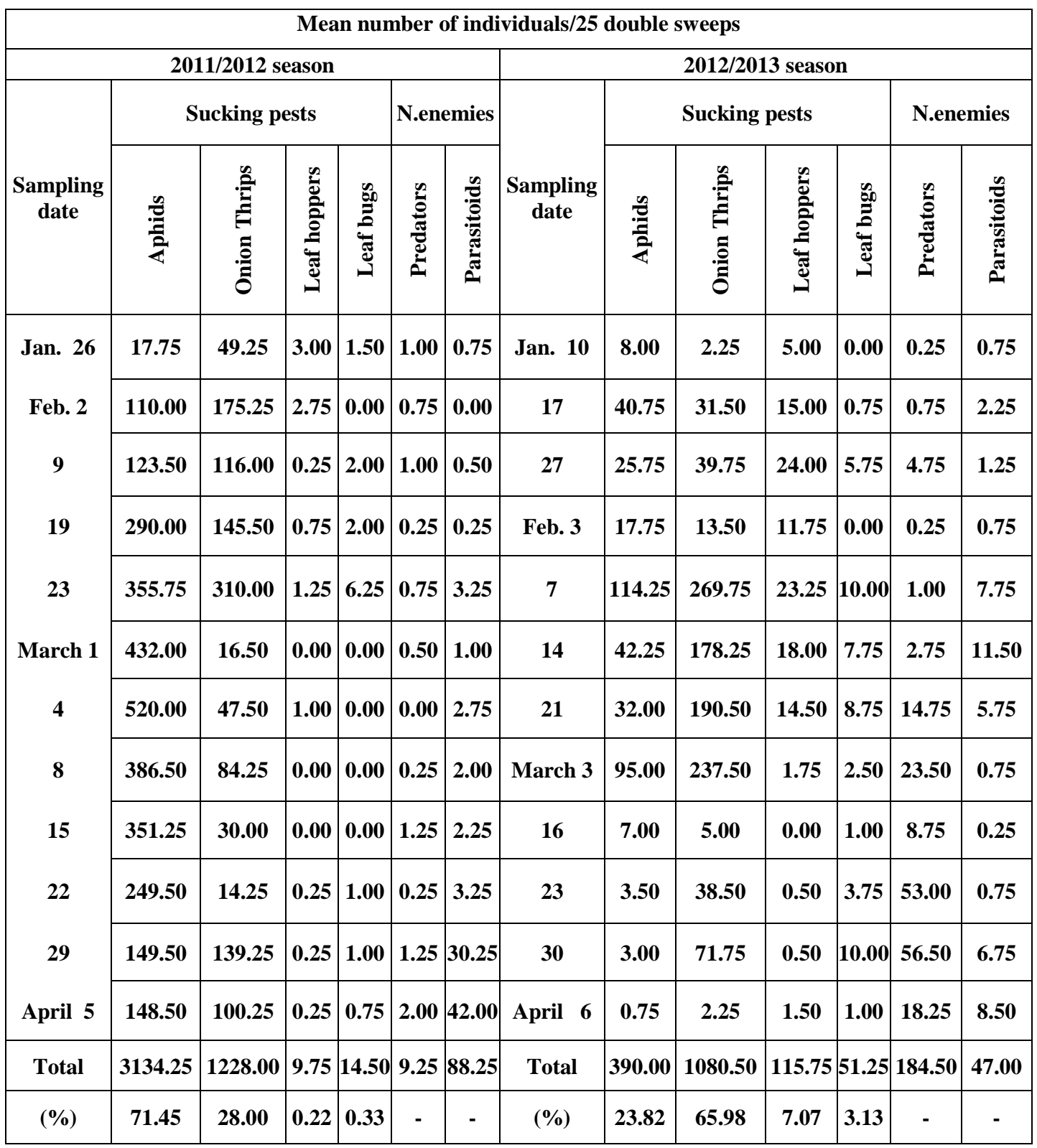


Table (3): Mean numbers of piercing-sucking pests infesting coriander plants and their natural enemies, Abnoub district, Assiut 2011/2012 and 2012/2013 seasons.

\begin{tabular}{|c|c|c|c|c|c|c|c|c|c|c|c|c|c|}
\hline \multicolumn{14}{|c|}{ Mean number of individuals/25 double sweeps } \\
\hline \multicolumn{7}{|c|}{ 2011/2012 season } & \multicolumn{7}{|c|}{ 2012/2013 seasons } \\
\hline \multirow[b]{2}{*}{$\begin{array}{c}\text { Sampling } \\
\text { date }\end{array}$} & \multicolumn{4}{|c|}{ Sucking pests } & \multicolumn{2}{|c|}{ N. enemies } & \multirow[b]{2}{*}{$\begin{array}{c}\text { Sampling } \\
\text { date }\end{array}$} & \multicolumn{4}{|c|}{ Sucking pests } & \multicolumn{2}{|c|}{ N. enemies } \\
\hline & $\frac{n}{\frac{0}{2}}$ & 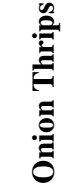 & 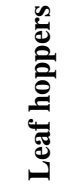 & 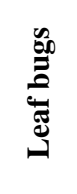 & 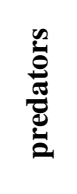 & 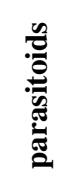 & & $\frac{n}{\frac{0}{2}}$ & 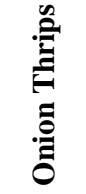 & 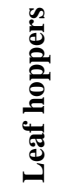 & 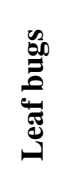 & 胥 & 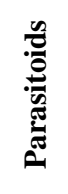 \\
\hline Dec. 29 & 0.00 & 0.00 & 0.00 & 0.00 & 0.00 & 0.00 & \multirow{2}{*}{$\begin{array}{c}\text { Dec. } 4 \\
14\end{array}$} & 0.00 & 0.00 & 0.00 & 0.00 & 0.00 & 0.00 \\
\hline Jan. 1 & 0.00 & 0.00 & 0.00 & 0.00 & 0.00 & 0.00 & & 0.25 & 2.00 & 0.25 & 0.00 & 0.00 & 0.00 \\
\hline 12 & 0.00 & 0.00 & 0.00 & 0.00 & 0.00 & 0.00 & \multirow{3}{*}{$\begin{array}{l}19 \\
26 \\
31\end{array}$} & 1.00 & 5.75 & 0.00 & 0.00 & 0.50 & 0.00 \\
\hline 19 & 0.00 & 0.00 & 0.00 & 0.00 & 0.00 & 0.00 & & 7.50 & 18.50 & 0.25 & 0.00 & 0.75 & 0.50 \\
\hline 26 & 0.00 & 0.00 & 0.25 & 0.00 & 0.25 & 0.00 & & 14.50 & 14.25 & 0.00 & 0.50 & 1.25 & 0.25 \\
\hline Feb. 2 & 0.75 & 0.25 & 0.00 & 0.00 & 0.00 & 0.00 & \multirow{2}{*}{$\begin{aligned} \text { Jan. } & 9 \\
15 & \end{aligned}$} & 32.00 & 25.50 & 0.25 & 0.00 & 1.25 & 0.25 \\
\hline 9 & 0.50 & 1.25 & 0.00 & 0.00 & 0.00 & 0.00 & & 43.50 & 28.25 & 0.00 & 0.25 & 1.50 & 0.50 \\
\hline 16 & 9.50 & 7.25 & 0.00 & 0.00 & 0.00 & 0.25 & \multirow{2}{*}{$\begin{array}{r}23 \\
30\end{array}$} & 17.75 & 3.50 & 0.00 & 0.25 & 3.00 & 0.00 \\
\hline 23 & 38.00 & 1.50 & 0.00 & 2.25 & 0.00 & 0.00 & & 130.50 & 12.75 & 0.00 & 0.00 & 2.50 & 0.50 \\
\hline March 1 & 29.00 & 0.00 & 0.00 & 0.50 & 0.00 & 0.25 & \multirow{2}{*}{$\begin{array}{r}\text { Feb. } 7 \\
14\end{array}$} & 232.00 & 14.25 & 0.00 & 0.25 & 16.50 & 2.00 \\
\hline 8 & 53.50 & 16.00 & 0.00 & 7.25 & 2.00 & 6.00 & & 305.75 & 17.25 & 0.00 & 0.25 & 13.50 & 1.25 \\
\hline 15 & 245.25 & 25.00 & 0.25 & 16.00 & 1.25 & 8.00 & \multirow{2}{*}{$\begin{array}{l}21 \\
28\end{array}$} & 220.75 & 19.00 & 0.00 & 0.25 & 5.00 & 0.75 \\
\hline 22 & 319.50 & 16.50 & 0.00 & 1.25 & 11.25 & 2.25 & & 201.00 & 8.50 & 0.50 & 0.00 & 6.25 & 0.00 \\
\hline 29 & 34.75 & 1.00 & 0.00 & 0.00 & 21.25 & 0.00 & March 9 & 138.25 & 2.00 & 0.50 & 0.75 & 1.25 & 0.25 \\
\hline Total & 730.75 & 68.75 & 0.50 & 27.25 & 36.00 & 16.75 & Total & 1344.75 & 171.50 & 1.75 & 2.50 & 53.25 & 6.25 \\
\hline$(\%)$ & 88.33 & 8.31 & 0.060 & 3.29 & - & - & $(\%)$ & 88.44 & 11.28 & 0.12 & 0.16 & - & - \\
\hline
\end{tabular}


Table (4): Population densities of aphid species infesting coriander plants in relation to some abiotic and biotic factors, Shotb, Assiut, 2011/2012.

\begin{tabular}{|c|c|c|c|c|c|c|c|c|c|}
\hline \multirow{4}{*}{$\begin{array}{l}\text { Sampling } \\
\text { date }\end{array}$} & \multicolumn{9}{|c|}{ Average no. of individuals /25 double sweeps } \\
\hline & \multirow{3}{*}{$\begin{array}{l}\text { (1)Total } \\
\text { aphids }\end{array}$} & \multicolumn{2}{|c|}{ Biotic factors } & \multicolumn{6}{|c|}{ Abiotic factors } \\
\hline & & \multirow{2}{*}{$\begin{array}{c}\text { Plant age } \\
\text { (days) }\end{array}$} & \multirow{2}{*}{$\begin{array}{l}\text { (2)Natural } \\
\text { enemies }\end{array}$} & \multicolumn{2}{|c|}{ Temperature $\circ \mathbf{C}$} & \multicolumn{2}{|c|}{ R.H. $(\%)$} & \multicolumn{2}{|c|}{ Soil temp. at $5 \mathrm{~cm}$} \\
\hline & & & & Max. & Min. & Max. & Min. & Max. & Min. \\
\hline Jan. 26 & 17.75 & 20 & 1.75 & 20.14 & 5.29 & 77.00 & 19.00 & 22.29 & 9.42 \\
\hline $\begin{array}{ll}\text { Feb. } 2 \\
\end{array}$ & 110.00 & 27 & 0.75 & 19.00 & 7.57 & 69.00 & 22.14 & 21.57 & 9.43 \\
\hline 9 & 123.50 & 34 & 1.50 & 19.50 & 6.86 & 69.71 & 14.29 & 21.29 & 10.00 \\
\hline 19 & 290.00 & 43 & 0.50 & 21.60 & 8.60 & 73.30 & 13.70 & 22.00 & 12.00 \\
\hline 23 & 355.75 & 47 & 4.00 & 24.00 & 6.25 & 78.75 & 23.50 & 26.00 & 11.25 \\
\hline March 1 & 432.00 & 54 & 1.50 & 22.71 & 8.57 & 72.14 & 19.00 & 26.57 & 12.29 \\
\hline 4 & 520.00 & 57 & 2.75 & 20.00 & 6.33 & 80.00 & 14.00 & 26.00 & 12.67 \\
\hline 8 & 386.50 & 61 & 2.25 & 25.00 & 8.00 & 81.50 & 17.25 & 30.50 & 13.75 \\
\hline 15 & 351.25 & 68 & 3.50 & 27.14 & 11.86 & 67.57 & 14.71 & 32.57 & 15.86 \\
\hline 22 & 249.50 & 75 & 3.50 & 22.86 & 6.57 & 78.57 & 14.57 & 30.00 & 13.71 \\
\hline 29 & 149.50 & 82 & 31.50 & 25.86 & 8.43 & 76.71 & 8.57 & 32.86 & 14.86 \\
\hline April 5 & 148.50 & 89 & 44.00 & 31.14 & 12.43 & 71.14 & 8.00 & 35.00 & 18.57 \\
\hline Total & 3134.25 & - & 97.50 & - & - & - & - & - & - \\
\hline
\end{tabular}

(1) Sum of the average number of the four aphid species (A. Craccivora, A. gossypii, M. persicae and $R$. maidis).

(2) Sum of the average number of predator and parasitoid species. 
Table (5): Population densities of aphid species infesting coriander plants in relation to some abiotic and biotic factors, Shotb, Assiut, 2012/2013.

\begin{tabular}{|c|c|c|c|c|c|c|c|c|c|}
\hline \multirow{4}{*}{$\begin{array}{c}\text { Sampling } \\
\text { date }\end{array}$} & \multicolumn{9}{|c|}{ Average no. of individuals $/ 25$ double sweeps } \\
\hline & \multirow{3}{*}{$\begin{array}{l}\text { (1)Total } \\
\text { aphids }\end{array}$} & \multicolumn{2}{|c|}{ Biotic factors } & \multicolumn{6}{|c|}{ Abiotic factors } \\
\hline & & \multirow{2}{*}{$\begin{array}{c}\text { Plant age } \\
\text { (days) }\end{array}$} & \multirow{2}{*}{$\begin{array}{l}\text { (2) Natural } \\
\text { enemies }\end{array}$} & \multicolumn{2}{|c|}{ Temperature $\circ \mathrm{C}$} & \multicolumn{2}{|c|}{ R.H. (\%) } & \multicolumn{2}{|c|}{ Soil temp. at $5 \mathrm{~cm}$} \\
\hline & & & & Max. & Min. & Max. & Min. & Max. & Min. \\
\hline Jan. 10 & 8.00 & 20 & 1.00 & 19.86 & 7.86 & 75.71 & 20.14 & 20.80 & 10.00 \\
\hline 17 & 40.75 & 27 & 3.00 & 21.43 & 7.00 & 77.57 & 21.29 & 22.00 & 8.86 \\
\hline 27 & 25.75 & 37 & 6.00 & 26.30 & 13.80 & 75.80 & 22.80 & 23.40 & 12.10 \\
\hline Feb. 3 & 17.75 & 4 & 1.00 & 25.86 & 12.57 & 83.57 & 27.57 & 22.71 & 10.14 \\
\hline 7 & 114.25 & 8 & 8.75 & 29.00 & 13.00 & 77.25 & 22.00 & 24.50 & 12.25 \\
\hline 14 & 42.25 & 3 & 14.25 & 27.71 & 11.71 & 78.71 & 18.29 & 25.86 & 11.86 \\
\hline 21 & 32.00 & 10 & 20.50 & 27.14 & 11.71 & 75.71 & 19.86 & 26.43 & 13.14 \\
\hline March 3 & 95.00 & 20 & 24.25 & 30.90 & 13.00 & 74.80 & 10.70 & 29.50 & 14.40 \\
\hline 16 & 7.00 & 33 & 9.00 & 31.00 & 12.62 & 74.31 & 8.69 & 34.62 & 17.16 \\
\hline 23 & 3.50 & 40 & 53.75 & 27.29 & 11.57 & 64.57 & 11.71 & 33.71 & 17.71 \\
\hline 30 & 3.00 & 47 & 63.25 & 32.00 & 11.29 & 75.86 & 4.86 & 35.57 & 17.00 \\
\hline April 6 & 0.75 & 54 & 26.75 & 34.43 & 14.86 & 70.57 & 10.71 & 37.29 & 20.00 \\
\hline Total & 390.00 & - & 231.50 & - & - & - & - & - & - \\
\hline
\end{tabular}

(1) Sum of the average number of the four aphid species (A. Craccivora, A. gossypii, M. persicae and $R$. maidis).

(2) Sum of the average number of predator and parasitoid species. 
Table (6): Population densities of aphid species infesting coriander plants in relation to some abiotic and biotic factors, Abnoub, Assiut, 2011/2012.

\begin{tabular}{|c|c|c|c|c|c|c|c|c|c|}
\hline \multirow{4}{*}{$\begin{array}{l}\text { Sampling } \\
\text { date }\end{array}$} & \multicolumn{9}{|c|}{ Average no. of individuals / 25 double sweeps } \\
\hline & \multirow{3}{*}{$\begin{array}{l}\text { (1)Total } \\
\text { aphids }\end{array}$} & \multicolumn{2}{|c|}{ Biotic factors } & \multicolumn{6}{|c|}{ Abiotic factors } \\
\hline & & \multirow{2}{*}{$\begin{array}{l}\text { Plant age } \\
\text { (days) }\end{array}$} & \multirow{2}{*}{$\begin{array}{l}\text { (2)Natural } \\
\text { enemies }\end{array}$} & \multicolumn{2}{|c|}{ Temperature ${ }^{\circ} \mathbf{C}$} & \multicolumn{2}{|c|}{ R.H. (\%) } & \multicolumn{2}{|c|}{ Soil temp. at $5 \mathrm{~cm}$} \\
\hline & & & & Max. & Min. & Max. & Min. & Max. & Min. \\
\hline Dec. 29 & 0.00 & 30 & $\mathbf{0 . 0 0}$ & 21.29 & 8.43 & 73.29 & 23.14 & 21.14 & 8.71 \\
\hline Jan. 5 & 0.00 & 37 & $\mathbf{0 . 0 0}$ & 19.50 & 7.63 & 78.75 & 22.88 & 19.29 & 9.00 \\
\hline 12 & 0.00 & 44 & 0.00 & 19.29 & 5.00 & 63.43 & 13.00 & 20.14 & 7.86 \\
\hline 19 & 0.00 & 51 & 0.00 & 18.43 & 4.71 & 79.75 & 17.29 & 20.71 & 8.86 \\
\hline 26 & 0.00 & 58 & 0.25 & 20.14 & 5.29 & 77.00 & 19.00 & 22.29 & 9.43 \\
\hline Feb. 2 & 0.75 & 65 & 0.00 & 19.00 & 7.57 & 69.00 & 22.14 & 21.57 & 10.43 \\
\hline 9 & 0.50 & 72 & 0.00 & 19.57 & 6.86 & 13.21 & 69.71 & 21.29 & 10.00 \\
\hline 16 & 9.50 & 79 & 0.25 & 22.43 & 9.71 & 72.29 & 17.29 & 20.57 & 12.14 \\
\hline 23 & 38.00 & 86 & 0.00 & 22.14 & 6.14 & 77.43 & 22.71 & 26.14 & 11.86 \\
\hline March 1 & 29.00 & 93 & 0.25 & 22.71 & 8.57 & 72.14 & 19.00 & 28.57 & 13.29 \\
\hline 8 & 53.50 & 100 & 8.00 & 22.85 & 7.28 & 80.86 & 15.86 & 32.57 & 15.86 \\
\hline 15 & 245.25 & 107 & 9.25 & 27.14 & 11.86 & 67.57 & 14.71 & 30.00 & 13.71 \\
\hline 22 & 319.50 & 114 & 13.50 & 22.86 & 6.57 & 78.57 & 14.57 & 30.00 & 13.71 \\
\hline 29 & 34.75 & 121 & 21.25 & 25.86 & 8.43 & 76.71 & 8.57 & 32.86 & 14.86 \\
\hline Total & 730.75 & - & 52.75 & - & - & - & - & - & - \\
\hline
\end{tabular}

(1) Sum of the average number of the four aphid species (A. Craccivora, A. gossypii, M. persicae and $R$. maidis).

(2) Sum of the average number of predator and parasitoid species. 
Table (7): Population densities of aphid species infesting coriander plants in relation to some abiotic and biotic factors, Abnoub, Assiut, 2012/2013.

\begin{tabular}{|c|c|c|c|c|c|c|c|c|c|}
\hline \multirow{4}{*}{$\begin{array}{l}\text { Sampling } \\
\text { date }\end{array}$} & \multicolumn{9}{|c|}{ Average no. of individuals / 25 double sweeps } \\
\hline & \multirow{3}{*}{$\begin{array}{l}\text { (1)Total } \\
\text { aphids }\end{array}$} & \multicolumn{2}{|c|}{ Biotic factors } & \multicolumn{6}{|c|}{ Abiotic factors } \\
\hline & & \multirow{2}{*}{$\begin{array}{l}\text { Plant age } \\
\text { (days) }\end{array}$} & \multirow{2}{*}{$\begin{array}{c}\text { (2)Natural } \\
\text { enemies }\end{array}$} & \multicolumn{2}{|c|}{ Temperature ${ }^{\circ} \mathbf{C}$} & \multicolumn{2}{|c|}{ R.H. (\%) } & \multicolumn{2}{|c|}{ Soil temp. at $5 \mathrm{~cm}$} \\
\hline & & & & Max. & Min. & Max. & Min. & Max. & Min. \\
\hline Dec. 4 & 0.00 & 20 & 0.00 & 29.57 & 12.43 & 74.00 & 13.29 & 27.86 & 15.29 \\
\hline 14 & 0.25 & 30 & 0.00 & 25.10 & 10.70 & 75.70 & 18.50 & 24.40 & 12.60 \\
\hline 19 & 1.00 & 35 & 0.50 & 24.40 & 10.50 & 79.80 & 18.50 & 24.60 & 12.20 \\
\hline 26 & 7.50 & 42 & 1.25 & 23.43 & 8.86 & 75.00 & 21.71 & 23.57 & 12.00 \\
\hline 31 & 14.50 & 47 & 1.50 & 25.20 & 12.20 & 83.40 & 24.80 & 22.40 & 10.80 \\
\hline Jan. 9 & 32.00 & 56 & 1.50 & 20.89 & 7.44 & 74.11 & 16.22 & 21.11 & 11.89 \\
\hline 15 & 43.50 & 62 & 2.00 & 20.00 & 7.00 & 77.67 & 22.00 & 21.71 & 8.43 \\
\hline 23 & 17.75 & 70 & 3.00 & 26.13 & 11.75 & 74.38 & 19.25 & 23.63 & 11.13 \\
\hline 30 & 130.50 & 77 & 3.00 & 25.43 & 14.29 & 79.43 & 27.57 & 22.14 & 11.86 \\
\hline Feb. 7 & 232.00 & 85 & 18.50 & 27.50 & 12.50 & 81.75 & 24.38 & 23.63 & 11.00 \\
\hline 14 & 305.75 & 92 & 14.75 & 27.71 & 11.71 & 78.71 & 18.29 & 25.86 & 11.86 \\
\hline 21 & 220.75 & 99 & 5.75 & 27.14 & 11.71 & 75.71 & 19.86 & 26.33 & 11.33 \\
\hline 28 & 201.00 & 106 & 6.25 & 31.14 & 13.29 & 79.57 & 13.14 & 27.86 & 13.43 \\
\hline March 9 & 138.25 & 115 & 1.50 & 28.33 & 11.67 & 6.44 & 8.44 & 31.11 & 15.00 \\
\hline Total & 1344.75 & & $\mathbf{5 9 . 5 0}$ & & & & & & \\
\hline
\end{tabular}

(1) Sum of the average number of the four aphid species (A. Craccivora, A. gossypii, M. persicae and R. maidis).

(2) Sum of the average number of predator and parasitoid species. 
Table (8) : Relationship between certain abiotic and biotic factors and the dynamics of aphid populations infesting coriander plants in two locations, Assiut, 2011/2012 and 2012/2013 seasons.

\begin{tabular}{|c|c|c|c|c|c|c|c|c|c|c|}
\hline \multirow{4}{*}{ 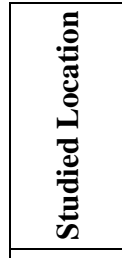 } & \multirow{4}{*}{ 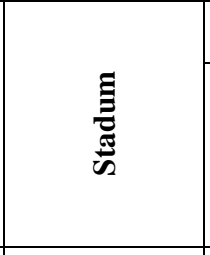 } & \multicolumn{9}{|c|}{ Variable removed } \\
\hline & & \multirow{3}{*}{ ż } & \multicolumn{6}{|c|}{ Abiotic factors } & \multicolumn{2}{|c|}{ Biotic factors } \\
\hline & & & \multicolumn{2}{|c|}{ Temperature ${ }^{\circ} \mathrm{c}$} & \multicolumn{2}{|c|}{ R.H. (\%) } & \multicolumn{2}{|c|}{ Soil temp. at $5 \mathrm{~cm}$} & \multirow{2}{*}{$\begin{array}{l}\text { Plant age } \\
\text { (days) }(\mathbf{x 1})\end{array}$} & \multirow{2}{*}{$\begin{array}{c}\text { Natural } \\
\text { enemies }(x 8)\end{array}$} \\
\hline & & & Max.(x2) & $\operatorname{Min} .(x 3)$ & Max.(x4) & Min. (x5) & Max.(x6) & Min. (x7) & & \\
\hline \multirow{3}{*}{ Shotb } & $\mathbf{R}$ & - & -0.37 & -0.35 & $-0.45 *$ & 0.13 & 0.03 & -0.02 & $0.52 *$ & -0.07 \\
\hline & $\mathbf{R} 2 \times 100$ & 58.49 & - & - & - & - & - & - & - & - \\
\hline & Efficiency (\%) & - & 20.34 & 0.03 & 3.73 & 2.26 & 2.35 & 1.56 & 23.46 & 4.76 \\
\hline \multirow{3}{*}{ Abnoub } & & - & $0.65^{*}$ & $0.49 *$ & 0.35 & 0.07 & -0.21 & 0.37 & $0.63 *$ & 0.18 \\
\hline & $\mathrm{R} 2 \times 100$ & 64.57 & - & - & - & - & - & - & - & - \\
\hline & Efficiency (\%) & - & 12.16 & 7.28 & 0.03 & 0.86 & 0.05 & 0.25 & 39.73 & 4.21 \\
\hline
\end{tabular}

$\mathbf{r}=$ Correlation coeffient.

$\mathbf{R}^{2}=$ Coefficient of determination .

*= Significant at $0.5 \%$ of probability. 


\section{الوفرة النسبية لأهم الآفات الثاقبة الماصة وها يصاحبها من أعداء حيوية علي نباتات الكربرة (Coriandrum sativum L.) في همافظة أسيوط}

$$
\begin{aligned}
& \text { (') علاء الدين عبد القادر احمد سالم، (') عبد العليم جابر علي،(؟) سميحة جاد الله عزب ، } \\
& \text { (ץ) (ץاء شحاتة محمد ، (') أميمة صابر محمود } \\
& \text { معه بحوث وقاية النباتات - مركز البحوث الزراعية - جيزة - مصر } \\
& \text { (†) قسم علم الحيوان -كلية العلوم-جامعة أسيوط- أسيوط- مصر }
\end{aligned}
$$

\section{المضص العربي:}

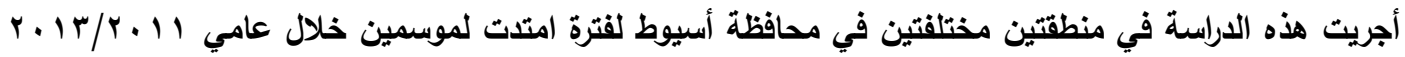
بهاف حصر لمفصليات الأرجل المصاحبة لنباتات الكزبرة، وكذلك دراسة التذبذبات والوفرة الموسمية لأهم الحشرات الثاقبة الماصة، هذا بالاضافة الي بيان ارتباط بعض العومل الغير حيوية وإلحيوية علي التغيرات التي تحدث في تعداد حشرات المن. ولقد كانت النتائج المتحصل لاصفه عليها كالآتي:

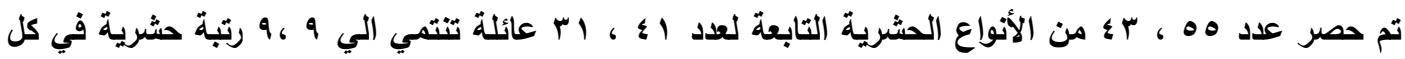

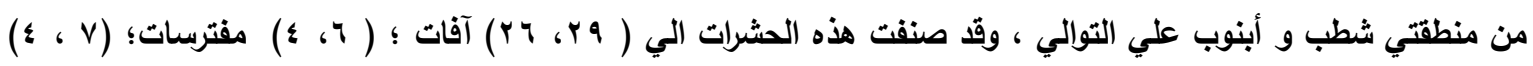
طفيليات و (17 ، ، 11 (1) ملقحات وحشرات زائرة في كل من شطب و أبنوب علي التوالي، كما بينت الدراسة ايضا أن رتبة

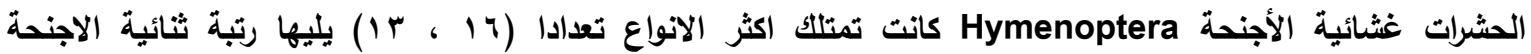
Diptera

بينت النتائج أيضا أنه خلال الموسمين أن حشرات المنّ (أنواع متعددة) كانت أكثر الحشرات الثاقبة الماصة وفرة

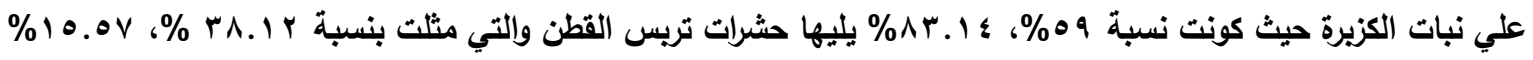

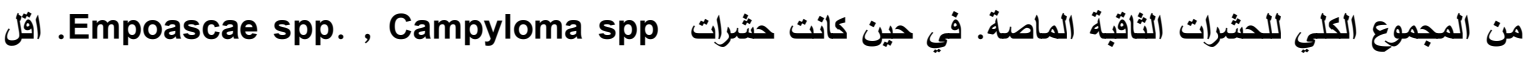

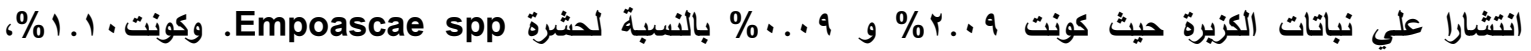

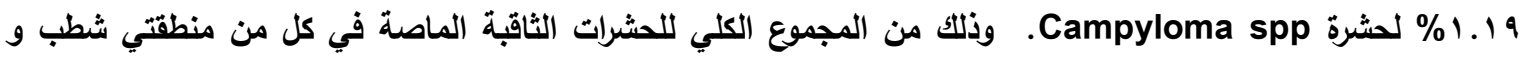
أبنوب علي الترتيب.

أظهرت نتائج التحليل الأحصائي أن العوامل المدروسة كاتت مرتبطة بالتغيرات في تعداد حشرات المن بحوالي

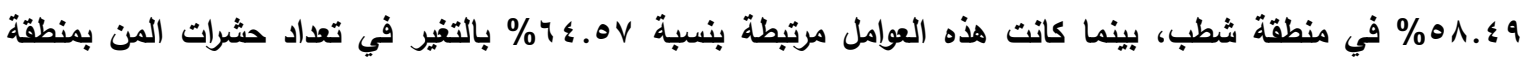

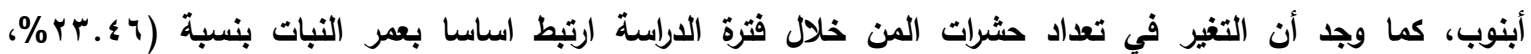

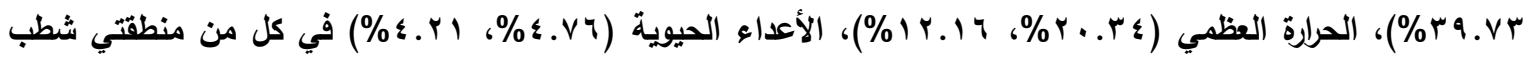

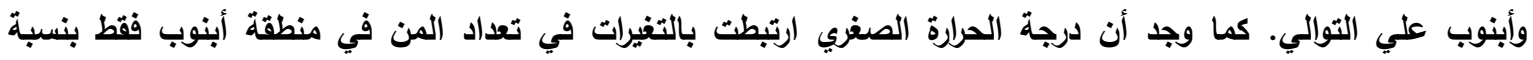

